\title{
Communication
}

\section{Genotyping of African Swine Fever Virus (ASFV) Isolates in Romania with the First Report of Genotype II in Symptomatic Pigs}

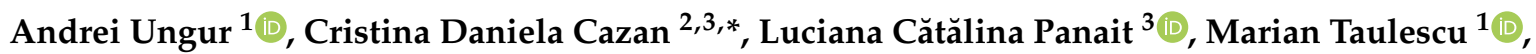 \\ Oana Maria Balmoș ${ }^{3}$, Marian Mihaiu ${ }^{4}$, Florica Bărbuceanu ${ }^{5}$, Andrei Daniel Mihalca ${ }^{3,6} \mathbb{C}^{\mathbb{D}}$ and Cornel Cătoi ${ }^{1,6}$
}

1 Department of Pathology, Faculty of Veterinary Medicine, University of Agricultural Sciences and Veterinary Medicine of Cluj-Napoca, Calea Mănăstur 3-5, 400372 Cluj-Napoca, Romania;

andrei.ungur@usamvcluj.ro (A.U.); marian.taulescu@usamvcluj.ro (M.T.); cornel.catoi@usamvcluj.ro (C.C.)

2 Molecular Biology and Veterinary Parasitology Unit (CDS-9), Faculty of Veterinary Medicine, University of Agricultural Sciences and Veterinary Medicine of Cluj-Napoca, Calea Mănăștur 3-5, 400372 Cluj-Napoca, Romania

3 Department of Parasitology and Parasitic Diseases, Faculty of Veterinary Medicine, University of Agricultural Sciences and Veterinary Medicine of Cluj-Napoca, Calea Mănăștur 3-5, 400372 Cluj-Napoca, Romania; luciana.rus@usamvcluj.ro (L.C.P.); oana-maria.balmos@usamvcluj.ro (O.M.B.); amihalca@usamvcluj.ro (A.D.M.)

4 Department of Food Safety, Faculty of Veterinary Medicine, University of Agricultural Sciences and Veterinary Medicine of Cluj-Napoca, Calea Mănăștur 3-5, 400372 Cluj-Napoca, Romania;

Citation: Ungur, A.; Cazan, C.D.; Panait, L.C.; Taulescu, M.; Balmoș, O.M.; Mihaiu, M.; Bărbuceanu, F.; Mihalca, A.D.; Cătoi, C. Genotyping of African Swine Fever Virus (ASFV) Isolates in Romania with the First Report of Genotype II in Symptomatic Pigs. Vet. Sci. 2021, 8, 290. https://doi.org/10.3390/ vetsci 8120290

Academic Editors: Ann Sofie Olesen and Anette Bøtner

Received: 9 November 2021

Accepted: 24 November 2021

Published: 26 November 2021

Publisher's Note: MDPI stays neutral with regard to jurisdictional claims in published maps and institutional affiliations.

Copyright: (c) 2021 by the authors. Licensee MDPI, Basel, Switzerland. This article is an open access article distributed under the terms and conditions of the Creative Commons Attribution (CC BY) license (https:/ / creativecommons.org/licenses/by/ $4.0 /)$. mihaiu.marian@usamvcluj.ro

5 Institute for Diagnosis and Animal Health, 050556 Bucharest, Romania; florica.barbuceanu@idah.ro

6 Technological Transfer Centre for Animal Nutrition and Comparative Pathology 'COMPAC' of the University of Agricultural Sciences and Veterinary Medicine of Cluj-Napoca, Calea Mănăștur 3-5, 400372 Cluj-Napoca, Romania

* Correspondence: cristina.cazan@usamvcluj.ro; Tel.: +40-7-4983-6629

Abstract: The World Organisation for Animal Health has listed African swine fever as the most important deadly disease in domestic swine around the world. The virus was recently brought from South-East Africa to Georgia in 2007, and it has since expanded to Russia, Eastern Europe, China, and Southeast Asia, having a devastating impact on the global swine industry and economy. In this study, we report for the first time the molecular characterization of nine African swine fever virus (ASFV) isolates obtained from domestic pigs in Mureş County, Romania. All nine Romanian samples clustered within p72 genotype II and showed 100\% identity with all compared isolates from Georgia, Armenia, Russia, Azerbaijan, Ukraine, Belarus, Lithuania, and Poland. This is the first report of ASFV genotype II in the country.

Keywords: African swine fever virus (ASFV); domestic pigs; genotype II; p72; Romania

\section{Introduction}

The World Organisation for Animal Health (OIE) considers African swine fever (ASF) one of the most severe and important disease affecting the domestic pig and wild boar populations around the world [1]. The high mortality rates among domestic pigs are also devastating to the swine industry, with severe effects on the economy [2]. The high economic impact in the swine industry is currently influenced by the lack of specific medical therapy [2]. No vaccine is currently available against the disease [2]. As no medical technologies have been developed yet against the disease, the only way to slow down the spreading of its etiological agent, African swine fever virus (ASFV), is to quarantine all affected regions. The swine populations that are positive to ASF are currently culled, and the carcasses are destroyed by incineration. In some circumstances, a prophylactic depopulation is also performed throughout the positive regions. Furthermore, the commercialization and movement of domestic pigs and pig products are prohibited. As a result, 
not only the lethality of ASF but also the control efforts inflict significant economic losses to all farms from all positive countries [3]. Considering that wild boar populations can be affected by ASFV in the same ways as domestic pigs, the control and eradication of the disease is considerably more challenging in the affected countries due to the free movement of wild boars and their active contaminant role [3].

ASF is a viral disease widespread in Africa, Asia, and Europe, with acute-to-chronic manifestation and a hemorrhagic character. Recent studies have disputed the highly contagious character and proved that ASF spreads rather slowly compared with other infectious diseases [4]. Both domestic pigs and wild boar populations are the main species affected. The disease is also characterized by severe hyperthermia, abortion, hyperemic areas in the skin, and hemorrhages in several internal organs. Several factors, such as the hosts' immune system status, route of infection, virulence, and dosage of virus, can severely influence the clinical course and the pathological features of the disease. The most virulent strains of ASFV give the most fulminant clinical form, peracute ASF, in which sudden death is noticed [5]. Severe and diffuse splenic enlargement with dark-black discoloration and increased friability of the parenchyma are the only gross features of this clinical form. In the acute form of ASF, the mortality can reach up to $100 \%$ during the first week. During the first week of ASFV evolution to a host, the predominant clinical manifestations include emesis, nasal discharge, bloody diarrhea, apathy, abortion, and cutaneous hyperemia. This clinical form tends to be the most common form of the disease, with the isolates being moderately to highly virulent. The postmortem findings include the ones from the peracute form, followed by hemorrhagic necrotizing lymphadenitis. In some situations, petechiae might be observed in several organs such as the heart, kidneys, and urinary bladder [6]. When the viral strains are moderately virulent, similar but less severe clinical signs occur, represented by the subacute form of ASF, and the gross findings are more intense than in the acute form. The chronic forms of ASF are caused by low-to-moderate virulence strains. The clinical signs include multifocal necrosis in the skin, intermittent fever, respiratory distress, arthritis, and loss of weight [5], and the gross features are represented by glomerulonephritis, chronic pericarditis, pneumonia, skin lesions, fibrinous arthritis, and pleural adhesions [7].

In the European continent, two circulating genotypes of ASFV were previously identified, each of them having a different place of origin. The genotype I incursion started in Portugal in 1960, spreading to Spain and several other European countries, and it was eradicated by 1995, with the exception of Sardinia, Italy, where it remained endemic [8]. ASFV genotype II was firstly reported in Georgia in 2007 [9]; since then, it has spread to countries in eastern and central Europe [1]. A recent study confirmed that the circulating strains of ASFV in Asia are derived from the ones in Europe and Russia [10]. ASF was first reported in the European Union in Lithuania in early 2014, and it has since spread to several European Union countries, including Romania [11]. An important factor in the epidemiology of ASFV are the wild boar populations [12]. This specific group plays a major role in the dissemination of ASFV in most affected countries, as a natural epidemiological reservoir, allowing the virus to persist in the environment indefinitely without the presence of any other susceptible animals or vectors [12]. The first confirmation of ASFV in Romania was in the summer of 2017, in a backyard holding in the north-western region of the country [13]. From the first outbreak, the situation rapidly escalated, and infections with ASFV were confirmed in all Romanian counties, in both domestic pigs and wild boars. The rapid, extensive spread of the virus in Romania may have been influenced by the traditional extensive rearing system represented by backyard farms, and its feeding, watering, and housing conditions [14].

ASFV is a member of the Asfivirus genus from the Asfarviridae family. It is a complex enveloped virus with an icosahedral morphology and a double-stranded DNA [15]. The main site of replication is the cytoplasm of the infected cells, although an earlier stage of nuclear DNA synthesis has been documented [16,17], DNA replication occurs in the perinuclear factory site about $6 \mathrm{~h}$ after infection. Enzymes essential for virus genome 
transcription and replication, as well as virion structural proteins, are encoded in the virus genome [18]. The genome sequence size varies between 170 kilo base pairs (kbp) and $194 \mathrm{kbp}$ long, and it is encoding around 150 to 167 open reading frames [19]. There are three main areas of the genome. The core region has around $125 \mathrm{kbp}$ and is always constant in its length, with size variations lower than $1.5 \%$. The core area is flanked on both ends by two highly variable regions [20]. There are zones of localized high variability within the central constant region, such as the CVR area within the B602L gene, caused by differences in the number of tandem repeats, some of which are utilized to distinguish different isolates [21]. Based on sequence differences in the C-terminal region of the B646L gene, which encodes the primary variable capsid protein p72, ASFV strains and isolates were classified into 24 genotypes, reported in eastern and southern Africa, with genotypes I and II having become established in other regions as well. To follow virus evolution across countries and regions, information based solely on the B646L can be used for an initial sequencing of the partial genome, but for a full genome sequence, the usage of sub-groupings based on intergenic sections is necessary [22].

From the first report of an ASF case in 2017, there were more than 3800 confirmed ASF outbreaks in Romania, with a countrywide distribution [23]. However, no data regarding the circulating genotypes are currently available in the country. The present study aimed to identify the circulating ASFV genotype in a county from the central part of Romania in the context of ASF outbreak.

\section{Materials and Methods}

In order to assess the ASFV genotype present in Romania, 9 previously extracted DNA blood samples from Veterinary Health and Food Safety Department (DSVSA) Cluj were randomly selected and molecularly investigated. The selected samples originated from Mureş County (central region of Romania). Sample details are shown in Table 1.

Table 1. African swine fever virus isolates selected for genotyping from wild boars and domestic pigs after virus isolation, Mureș County, Romania, 2020.

\begin{tabular}{ccccc}
\hline Isolate & Host & Locality & p72 Genotype & GenBank Accession Number \\
\hline R31/17/2020 & wild boar & hunting domain 63, Târnăveni & II & OK623917 \\
R31/18/2020 & wild boar & hunting domain 63, Târnăveni & II & OK623918 \\
R31/19/2020 & wild boar & hunting domain 63, Târnăveni & II & OK623919 \\
R71/22/2020 & domestic pig & Dâmbău & II & OK623920 \\
R71/23/2020 & domestic pig & Dâmbău & II & OK623921 \\
R77/45/2020 & domestic pig & Gănești & II & OK623922 \\
R88/4/2020 & domestic pig & Iernut & II & OK623923 \\
R88/5/2020 & domestic pig & Iernut & II & OK623925 \\
R91/31/2020 & wild boar & hunting domain 7, Papiu & II & \\
\hline
\end{tabular}

For the p72 genotype classification, the C-terminal region of the p72 protein gene (B646L) was amplified by conventional polymerase chain reaction (PCR). PCR amplification of the B646L gene region ( $\sim 78 \mathrm{bp})$ was performed in a total volume of $25 \mu \mathrm{L}$, containing $12.5 \mu \mathrm{L}$ Red PCR Mastermix (Bioline Meridian Bioscience, Luckenwalde, Germany), $6.5 \mu \mathrm{L}$ of ultrapure water, $1 \mu \mathrm{L}(10 \mathrm{pmol} / \mu \mathrm{L})$ of each of the two previously described primers p72-D (5'-GGCACAAGTTCGGACATGT- $\left.3^{\prime}\right)$ and p72-U (5'-TACTGTAACGCAGCACAG$\left.3^{\prime}\right)$ [24] and $4 \mu \mathrm{L}$ aliquot of the previously isolated DNA. One negative control containing $4 \mu \mathrm{L}$ ultra-pure water instead of DNA was included. The PCR was performed using the $\mathrm{T}_{1000^{\mathrm{TM}}}$ Thermal Cycler (Bio-Rad, London, UK). The reaction was performed with the following conditions: initial denaturation at $95{ }^{\circ} \mathrm{C}$ for $1 \mathrm{~min}$, followed by 35 cycles of denaturation at $95^{\circ} \mathrm{C}$ for $15 \mathrm{~s}$, annealing at $54{ }^{\circ} \mathrm{C}$ for $15 \mathrm{~s}$ and extension at $72{ }^{\circ} \mathrm{C}$ for $10 \mathrm{~s}$, with a final extension at $72{ }^{\circ} \mathrm{C}$ for $5 \mathrm{~s}$. Electrophoresis was used to visualize the amplification products on $1.5 \%$ agarose gel stained with ECO Safe 20,000 $\times$ Nucleic Acid Staining Solution (Pacific Image Electronics, New Taipei, Taiwan). The molecular weight of the samples was assessed by comparison to a molecular marker (O'GeneRuler ${ }^{\mathrm{TM}} 100$ bp DNA 
Ladder, Thermo Fisher Scientific Inc., Waltham, MA, USA). All PCR products previously visualized were purified using the ISOLATE II PCR and Gel Kit (Bioline Meridian Bioscience, Luckenwalde, Germany). The sequencing was performed by a private company (Macrogen Europe, Amsterdam, the Netherlands). The obtained sequences were compared with those available in GenBank ${ }^{\mathrm{TM}}$ using Basic Local Alignments Tool (BLAST) analyses. All sequences were analyzed and edited using Geneious ${ }^{\circledR} 4.85$ software [25].

To investigate the phylogenetic analyses among ASFV genotypes, a phylogenetic tree of the B646L gene region was constructed based on all unique sequences obtained in the current study and those available in GenBank. The ASFV genotype II sequences selected from GenBank originated in Georgia (JX857509), Armenia (JX857508), Azerbaijan (JX857515), Belarus (KJ627215), Russia (JX857510), Lithuania (KJ627216), Poland (KJ627218) and Ukraine (JX857521). One B646L sequence of ASFV genotype IX from Congo (HQ645947) was used as an outgroup. The evolutionary history was inferred by using the maximum likelihood method and Jukes-Cantor model [26]. The tree with the highest log likelihood (-586.90) is shown. The percentage of trees in which the associated taxa clustered together is shown next to the branches. Initial tree(s) for the heuristic search were obtained automatically by applying Neighbor-Join and BioNJ algorithms to a matrix of pairwise distances estimated using the Jukes-Cantor model and then selecting the topology with superior log likelihood value. The tree is drawn to scale, with branch lengths measured in the number of substitutions per site. This analysis involved 19 nucleotide sequences. Codon positions included were 1st+2nd+3rd+Noncoding. There was a total of 404 positions in the final dataset. Evolutionary analyses were conducted in MEGA X [27].

\section{Results}

The presence of the viral DNA was confirmed in all nine tested samples. All positive samples were successfully sequenced and phylogenetically analyzed for p72 (B646L) targeted gene. The ASFV Romanian samples clustered within p72 genotype II and showed 100\% identity with all compared ASFV isolates from Georgia (JX857509), Armenia (JX857508), Azerbaijan (JX857515), Belarus (KJ627215), Russia (JX857510), Lithuania (KJ627216), Poland (KJ627218), and Ukraine (JX857521) (Figure 1). This is the first report of ASFV genotype II in Romania. The nine Romanian sequences were deposited in GenBank database under the accession numbers OK623917-OK623925.

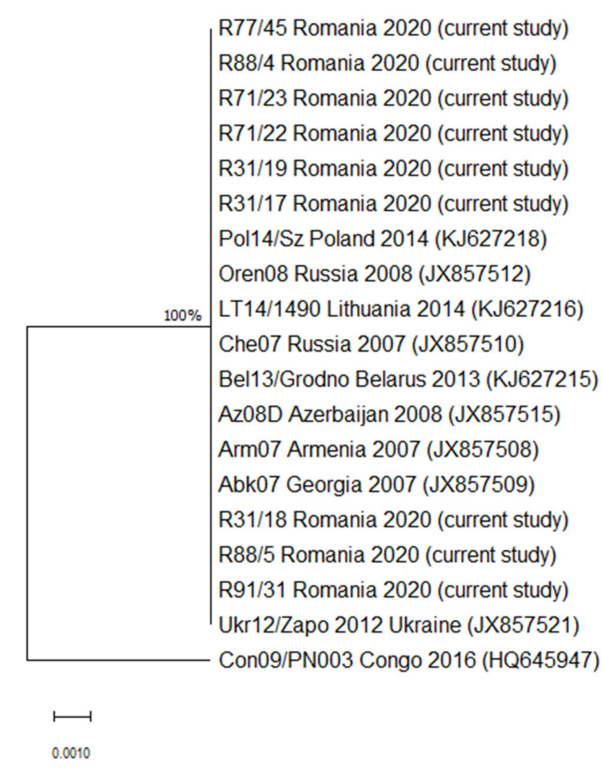

Figure 1. Maximum likelihood tree based on partial p72 B646L rDNA sequences obtained in the current study and sequences of ASFV genotype II (GenBank). Only bootstrap values above 75\% are displayed. The scale bar indicates the number of nucleotide substitutions per site. The Gen-Bank accession number, assigned name, and country of origin are indicated for each sequence, if available. 


\section{Discussion}

In the current study, we reported the first partial genome sequence of the circulating ASFV strain in the central region of Romania. As the number of ASF outbreaks in Romania and adjacent countries in Europe grows, scientists are finding it more difficult to pinpoint the spatial and temporal routes of ASFVs producing outbreaks as all ASFVs belong to genotype II. A growing number of complete genomes ASFV sequences obtained from countries around Romania are now available in GenBank, such as the ones from Russia (KP843857), Georgia (FR682468), or Poland (MH681419). Genotype II p72 group ASFV represents by far the most geographically widespread of the 24 viral genotypes currently known, owing to its recent introduction to Georgia and rapid subsequent dissemination north to the Russian Federation, west as far as east Germany, then east to China and other regions in southeastern Asia [28].

Recent studies conducted in China have confirmed that the ASFV strain circulating in the country was derived from an introduction of ASFV strains circulating in Europe and Russia, showing nucleotide identities of $99.944 \%, 99.951 \%$, and $99.972 \%$ with strains from Russia (KP843857), Georgia (FR682468), and Poland (MH681419) [10].

Our genomic data were compared to the most similar partial genome sequences in GenBank [21]; however, none of them differed genetically from the others. All sequenced from the present study showed $100 \%$ similarity with all compared ASFV isolates from the previously mentioned countries [21]. All the compared isolates have the same patterns for specific variable regions and cannot be separated into subgroups, suggesting that all the ASF outbreaks in both domestic and wild pigs from Eastern Europe might have the same starting point. The geographical spread of the disease and its distribution can be followed using the timeline of all reported outbreaks in this region, considering that ASFV is very stable and has a long resistance period in both death carcasses and the environment [29]. However, the genotype and subtype analyses of ASFV do not offer enough information regarding the specific source of infection in outbreaks. Other data are necessary, such as historical data and anamnesis in each farm, in order to establish the link between the outbreaks and the possible source of infections [30,31].

\section{Conclusions}

Genetic typing, nucleotide sequencing, and subsequent phylogenetic studies are used to confirm epidemiological data on a qualitatively different level all over the world. It also allows to track the evolution of viruses throughout time. The additional genomic information presented in this work adds to our understanding of the ASFV's geographical expansion and biological evolution, which can help in developing disease prevention and control techniques. This is the first study evaluating the ASFV genotypes in Romania and the first report of genotype II circulating in the central region of the country. However, more phylogenomic work is needed as the present data could not be generalized to the entire Romanian territory.

Author Contributions: Conceptualization, A.U., C.D.C. and M.T.; methodology, C.D.C., O.M.B. and L.C.P.; validation, M.M., F.B. and C.C.; formal analysis, A.D.M.; investigation, A.U. and C.D.C.; resources, F.B.; data curation, C.D.C. and M.T.; writing—original draft preparation, A.U.; writingreview and editing, C.D.C., M.T. and A.D.M.; visualization, C.D.C. and M.T.; supervision, M.M. and C.C.; project administration, C.D.C.; funding acquisition, A.U., C.D.C., A.D.M. and C.C. All authors have read and agreed to the published version of the manuscript.

Funding: This research was funded by European Social Found, Human Capital Operational Programme 2014-2020, grant number POCU/380/6/13/125171 and the University of Agricultural Sciences and Veterinary Medicine of Cluj-Napoca, Romania, grant number SOLUTII/USAMVCN/24873/ 2021. The work of C.D.C. was supported by a Romanian Ministry of Education and Research, CNCS-UEFISCDI, grant number PN-III-P1-1.1-PD-2019-0598, within PNCDI III. The publication was supported by funds from CNFIS-FDI-2021-0013.

Institutional Review Board Statement: Not applicable. 
Informed Consent Statement: Not applicable.

Data Availability Statement: All data generated or analyzed during this study are included in this article.

Conflicts of Interest: The authors declare no conflict of interest. The funders had no role in the design of the study; in the collection, analyses, or interpretation of data; in the writing of the manuscript, or in the decision to publish the results.

\section{References}

1. World Organisation for Animal Health. Available online: https://www.oie.int/en/disease/african-swine-fever/ (accessed on 30 July 2021).

2. Njau, E.P.; Domelevo Entfellner, J.B.; Machuka, E.M.; Bochere, E.N.; Cleaveland, S.; Shirma, G.M.; Kusiluka, L.J.; Upton, C.; Bishop, R.P.; Pelle, R.; et al. The first genotype II African swine fever virus isolated in Africa provides insight into the current Eurasian pandemic. Sci. Rep. 2021, 11, 13081. [CrossRef]

3. Halasa, T.; Bøtner, A.; Mortensen, S.; Christensen, H.; Toft, N.; Boklund, A. Simulating the epidemiological and economic effects of an African swine fever epidemic in industrialized swine populations. Vet. Microbiol. 2016, 193, 7-16. [CrossRef]

4. Busch, F.; Haumont, C.; Penrith, M.L.; Laddomada, A.; Dietze, K.; Globig, A.; Guberti, V.; Zani, L.; Depner, K. Evidence-based African Swine Fever Policies: Do We Address Virus and Host Adequately? Front. Vet. Sci. 2021, 8, 637487. [CrossRef]

5. Sanchez-Vizcaino, J.M.; Mur, L.; Gomez-Villamandos, J.C.; Carrasco, L. An update on the epidemiology and pathology of African swine fever. J. Comp. Pathol. 2015, 152, 9-21. [CrossRef]

6. Gomez-Villamandos, J.C.; Bautista, M.J.; Sanchez-Cordon, P.J.; Carrasco, L. Pathology of African swine fever: The role of monocyte-macrophage. Virus Res. 2013, 173, 140-149. [CrossRef]

7. Moulton, J.; Coggins, L. Comparison of lesions in acute and chronic African swine fever. Cornell. Vet. 1968, 58, 364-388.

8. Costard, S.; Wieland, B.; de Glanville, W.; Jori, F.; Rowlands, R.; Vosloo, W.; Roger, F.; Pfeiffer, D.U.; Dixon, L.K. African swine fever: How can global spread be prevented? Philos. Trans. R. Soc. B Biol. Sci. 2009, 364, 2683-2696. [CrossRef]

9. Rowlands, R.J.; Michaud, V.; Heath, L.; Hutchings, G.; Oura, C.; Vosloo, W.; Dwarka, R.; Onashvili, T.; Albina, E.; Dixon, L.K. African Swine Fever Virus Isolate, Georgia, 2007. Emerg. Infect. Dis. 2008, 14, 1870-1874. [CrossRef]

10. Bao, J.; Wang, Q.; Lin, P.; Liu, C.; Li, L.; Wu, X.; Chi, T.; Xu, T.; Ge, S.; Liu, Y.; et al. Genome comparison of African swine fever virus China/2018/AnhuiXCGQ strain and related European p72 Genotype II strains. Transbound. Emerg. Dis. 2019, 66, 1167-1176. [CrossRef]

11. Gervasi, V.; Marcon, A.; Bellini, S.; Guberti, V. Evaluation of the Efficiency of Active and Passive Surveillance in the Detection of African Swine Fever in Wild Boar. Vet. Sci. 2020, 7, 5. [CrossRef]

12. Chenais, E.; Sternberg-Lewerin, S.; Boqvist, S.; Liu, L.; LeBlanc, N.; Aliro, T.; Masembe, C.; Ståhl, K. African swine fever outbreak on a medium-sized farm in Uganda: Biosecurity breaches and within-farm virus contamination. Trop. Anim. Health Prod. 2017, 49, 337-346. [CrossRef]

13. World Organisation for Animal Health. Available online: https://rr-europe.oie.int/wp-content/uploads/2020/04/2017-12_sgeasf_romania_en.pdf (accessed on 30 July 2021).

14. Boklund, A.; Dhollander, S.; Vasile, T.C.; Abrahantes, J.C.; Bøtner, A.; Gogin, A.; Villeta, L.G.; Gortázar, C.; More, S.J.; Papanikolaou, A.; et al. Risk factors for African swine fever incursion in Romanian domestic farms during 2019. Sci. Rep. 2020, $10,10215$. [CrossRef] [PubMed]

15. Ortín, J.; Enjuanes, L.; Viñuela, E. Cross-links in African swine fever virus DNA. Virol. J. 1979, 31, 579-583. [CrossRef]

16. Simões, M.; Rino, J.; Pinheiro, I.; Martins, C.; Ferreira, F. Alterations of Nuclear Architecture and Epigenetic Signatures during African Swine Fever Virus Infection. Viruses 2015, 7, 4978-4996. [CrossRef]

17. Simões, M.; Martins, C.; Ferreira, F. Early intranuclear replication of African swine fever virus genome modifies the landscape of the host cell nucleus. Virus Res. 2015, 210, 1-7. [CrossRef]

18. Dixon, L.K.; Chapman, D.A.; Netherton, C.L.; Upton, C. African swine fever virus replication and genomics. Virus Res. 2013, 173, 3-14. [CrossRef] [PubMed]

19. Mileto, P.; da Conceicao, F.; Stevens, V.; Cummins, D.; Certoma, A.; Neave, M.J.; da Costa Jong, J.B.; Williams, D.T. Complete Genome Sequence of African Swine Fever Virus Isolated from a Domestic Pig in Timor-Leste, 2019. Vet. Microbiol. 2021, 10, e00263-21. [CrossRef]

20. Mazloum, A.; van Schalkwyk, A.; Shotin, A.; Igolkin, A.; Shevchenko, I.; Gruzdev, K.N.; Vlasova, N. Comparative Analysis of Full Genome Sequences of African Swine Fever Virus Isolates Taken from Wild Boars in Russia in 2019. Pathogens 2021, 10, 521. [CrossRef] [PubMed]

21. Gallardo, C.; Fernandez-Pinero, J.; Pelayo, V.; Gazaev, I.; Markowska-Daniel, I.; Pridotkas, G.; Nieto, R.; Fernandez-Pacheco, P.; Bokhan, S.; Nevolko, O.; et al. Genetic variation among African swine fever genotype II viruses, Eastern and Central Europe. Emerg. Infect. Dis. 2014, 20, 1544-1547. [CrossRef]

22. Quembo, C.J.; Jori, F.; Vosloo, W.; Heath, L. Genetic characterization of African swine fever virus isolates from soft ticks at the wildlife/domestic interface in Mozambique and identification of a novel genotype. Transbound. Emerg. Dis. 2018, 65, 420-431. [CrossRef] 
23. Ardelean, F.; Globig, A.; Gârdan Năvălici, A.I.; Blome, S.; Dietze, K.; Depner, K.; Zani, L. The course of African swine fever in Romanian backyard holdings-A case report. Vet. Med. Sci. 2021, 7, 2273-2279. [CrossRef]

24. Bastos, A.D.; Penrith, M.L.; Cruciere, C.; Edrich, J.L.; Hutchings, G.; Roger, F.; Couacy-Hymann, E.; Thomson, R. Genotyping field strains of African swine fever virus by partial p72 gene characterization. Arch. Virol. 2003, 148, 93-706. [CrossRef] [PubMed]

25. Kearse, M.; Moir, R.; Wilson, A.; Stones-Havas, S.; Cheung, M.; Sturrock, S.; Buxton, S.; Cooper, A.; Markowitz, S.; Duran, C.; et al. Geneious basic: An integrated and extendable desktop software platform or the organization and analysis of sequence data. Bioinformatics 2012, 28, 1647-1679. [CrossRef] [PubMed]

26. Jukes, T.H.; Cantor, C.R. Evolution of protein molecules. In Mammalian Protein Metabolism; Munro, H.N., Ed.; Academic Press: New York, NY, USA, 1969; pp. 21-132.

27. Kumar, S.; Stecher, G.; Li, M.; Knyaz, C.; Tamura, K. MEGA X: Molecular Evolutionary Genetics Analysis across computing platforms. Mol. Biol. Evol. 2018, 35, 1547-1549. [CrossRef]

28. Sánchez-Cordón, P.J.; Montoya, M.; Reis, A.L.; Dixon, L.K. African swine fever: A re-emerging viral disease threatening the global pig industry. Vet. J. 2018, 233, 41-48. [CrossRef]

29. Fischer, M.; Hühr, J.; Blome, S.; Conraths, F.J.; Probst, C. Stability of African Swine Fever Virus in Carcasses of Domestic Pigs and Wild Boar Experimentally Infected with the ASFV “Estonia 2014" Isolate. Viruses 2020, 12, 1118. [CrossRef] [PubMed]

30. Goller, K.V.; Malogolovkin, A.; Katorkin, S.; Kolbasov, D.; Titov, I.; Höper, D.; Beer, M.; Keil, G.; Portugal, R.; Blome, S. Tandem Repeat Insertion in African Swine Fever Virus, Russia, 2012. Emerg. Infect. Dis. 2015, 21, 731-732. [CrossRef]

31. Kolbasov, D.; Titov, I.; Tsybanov, S.; Gogin, A.; Malogolovkin, A. African Swine Fever Virus, Siberia, Russia, 2017. Emerg. Infect. Dis. 2018, 24, 796-798. [CrossRef] [PubMed] 